\title{
Seasonality of respiratory syncytial virus - lower respiratory tract infection (RSV-LRTI) in children in developing countries
}

\begin{abstract}
Respiratory Syncytial Virus (RSV), an enveloped RNA virus with a non-segmented singlestranded negative-sense genome, is the primary cause of hospitalization in the first year of life for children in most parts of the world. The global estimate in 2005 indicated that at least 33.8 million episodes of RSV associated acute lower respiratory infection (ALRI) occurred worldwide in children younger than 5 years and most of these deaths occurred in developing countries. This study aimed to systematically aggregate and analyze published epidemiological data on the seasonality of RSV lower respiratory tract infections in young children in developing countries. Articles in English published between 2002 and 2014 were identified through literature searches in PubMed, Web of knowledge, and . The season in which RSV epidemics occur typically depends on geographical location and altitude. It is likely that several factors interact in complex ways in the development of epidemics under favorable climatic conditions.
\end{abstract}

Keywords: respiratory syncytial virus, rsv; seasonality; lower respiratory tract infection; children; developing countries
Volume 3 Issue I - 2016

\author{
Sirintip Sricharoenchai, ${ }^{1,2}$ Emanuela Palla, ${ }^{3}$ \\ Melvin Sanicas' \\ 'University di Siena, Italy \\ 2Department of Pediatrics, Siriraj Hospital Mahidol University, \\ Thailand \\ ${ }^{3}$ Novartis Vaccines and Diagnostics, Italy
}

Correspondence: Sirintip Sricharoenchai, Department of Pediatrics, Siriraj Hospital Mahidol University, Pediatric Infectious Diseases Unit, 2 Prannok Road, Bangkok 10700, Thailand, Email sirintipsri@gmail.com

Received: December 27, 2015 | Published: January II, 2016

\section{Introduction}

Lower respiratory tract infection (LRTI) is the leading global cause of death in children between 1 month and 5 years of age. ${ }^{1-4}$ Clinical characteristics of RSV infection include upper respiratory infection with rhinorrhea and nasal congestion lasting between 7 and 12 days. Re-infection rates vary between $6 \%$ and $83 \%$ each year, showing that initial infection does not confer immunity to succeeding infection. ${ }^{5}$ By the age of 2 years, nearly all children have had RSV infection. ${ }^{6}$ More serious disease involving the lower respiratory tract may develop in older children especially in immunocompromised and cardiopulmonary disease patients. ${ }^{7,8}$ RSV season varies over time and from location to location. ${ }^{910}$ The start and end of RSV season can vary year to year, state to state, and can even vary within communities in the same region. ${ }^{9,11}$

In countries with temperate climates, RSV causes epidemics of LRTI among infants and young children during late fall, winter, and early spring. In temperate climate regions, the RSV epidemic pattern depends on the temperature rather than the rainfall pattern. Most communities with temperate climates have a well-defined season of 3 to 5 months usually starting in the Northern hemisphere in October or November and continuing until February or March, followed by a peak in activity in the Southern hemisphere. In the southern hemisphere, wintertime epidemics occur from May to September. In addition, RSV studies conducted in temperate climates have identified a biannual pattern in the peak of RSV epidemics and RSV hospitalization rates, whereby the severity of RSV seasons alternates between milder and more severe. However, this is not predictable, and the differences may be more related to climatic changes. ${ }^{12}$

This study aimed to systematically aggregate and analyze published epidemiological data on the seasonality of RSV lower respiratory tract infection in young children in developing countries (Table 1).

\section{Materials and methods}

Potentially relevant published articles were identified through literature searches of the following bibliographic databases: PubMed,
Web of knowledge, and Embase. To access publications from developing countries that might not be included in those databases, searches in SciELO, Indian MEDLARS, Bioline International, and African Journals online were also performed. The following combination of MesH terms (Medical Subject Heading terms) and individual search terms were used: (Respiratory Syncytial Viruses OR pneumonia OR bronchiolitis OR respiratory tract infections) AND (developing country OR each individual country of the developing countries) for the epidemiological review, and (Respiratory Syncytial Viruses AND vaccine) for the review of vaccine development updates. The searches were restricted to studies of human subjects that were published in English between 2002 and 2014. Manual searches of reference from potentially relevant articles were also performed to identify additional studies that may have been missed using the computer-assisted strategy. For the purpose of this review, the developing countries were defined as the ones designated as such by either World Bank (low, lower middle and upper middleincome countries) or World Health Organization. Countries with a contradiction of development status classification between World Bank and WHO were included within the developing countries group for this review.

\section{Results and discussion}

In tropical or semitropical climates, RSV outbreaks are frequently associated with the rainy rather than the colder season. The variation is less apparent in the tropics, where there is small fluctuation in ambient temperature. RSV epidemics appear regularly but with different patterns of seasonality. In northern tropical areas, the seasonality seems to be associated with a decrease in temperature and an increase in rainfall. In the equatorial regions, RSV appears to be present most of the year. There are definitely 7 to 8 months of the year when the prevalence is higher than in the other 4 or 5 months, with some increase during the dry months. Tropical areas south of equator have a seasonality that is associated with decrease in both temperature and rainfall. Geographic and climatic factors are clearly associated with epidemics, but it is uncertain whether this is related to spread 
of the virus, behavioral factors, or cyclic changes in a population's immunologic susceptibility. ${ }^{13,14}$

The concept of RSV epidemic seasonality across continents and within geographic areas has been addressed in some of the reviewed publications. Here we present a summary of the publications from Africa, Latin America, Eastern Mediterranean, Europe, Southeast Asia and Western Pacific.

\section{Africa}

Reviewed articles were from Southern Africa, West Africa, and East Africa. No information on seasonality could be obtained from or Central and North Africa. The association of RSV epidemic periods with the wet seasons in tropical African countries is similar to observations of other studies from tropical countries with seasonal rainfall. The typical RSV season corresponded to the cold season in South Africa, where a temperate climate is observed. The discrepancy found within the countries might be due to interannual variation on viral seasonality.

The epidemic peak generally starts early in east African countries (Kenya, Mozambique) and South Africa then progresses to the West African countries (Senegal, Gambia, Ghana, Nigeria). The overall picture of RSV seasonality is in line with a previous publication describing that epidemics start at the very southern coast of Africa during the early period of the year and then move northward during the next 6 months. ${ }^{13}$ The isolation of RSV throughout the year in some African countries may be explained by the tropical climate and the concurrent HIV epidemic in the population which results in prolonged carriage of RSV and less evident seasonality.

\section{Latin America}

The seasonality studies in Latin America are from 4 countries -Mexico, Brazil, Argentina, and Chile. Mexico experiences the earliest RSV season, followed by Argentina and Chile. The seasonality of the RSV epidemics agrees with data from a previous study which found that epidemics occurred from north to south in South America. ${ }^{13}$ Studies from Brazil have shown a diversified seasonal pattern for $\mathrm{RSV}$, probably related to the wide diversity of climate characteristics in the country. While in the north, ${ }^{15-31}$ rainfall is the main climatic determinant, temperature variations play a more significant role in the south. RSV infections peaked in the coldest months in southern Brazil, ${ }^{32}$ the only region with temperate climate, similar to that

Table I Seasonality of RSV respiratory illnesses in Africa observed in Argentina and Chile. In southeast region, the peak of RSV outbreaks have not been associated with rainy seasons nor the coldest months and the epidemics appeared to spread throughout many months ${ }^{33-40}$ with one study detecting RSV cases throughout the year $^{41}$ (Table 2).

\section{Eastern Mediterranean}

In desert climates, RSV infection has been associated with the cold season, a finding consistent with the pattern found in this review. ${ }^{14}$ The study from United Arab Emirates provided inconclusive data defining RSV seasonality as it was conducted for only 3 months (September to November). ${ }^{54}$ Seven out of eleven studies from the Eastern Mediterranean were spanned only for short periods less than 12 months, and probably were insufficient to obtain information on seasonality $^{42-57}$ (Table 3).

\section{Europe}

The quality and quantity of RSV seasonality information of developing European countries within the past 10 years was poor, and each available study covered only short periods (5-8 months). ${ }^{58-60}$ Additionally, a study from Russia reported an unexpected factor of climate abnormality as a reminder that a single season may not be representative of the RSV season from year to year. ${ }^{58}$ Broader and longer studies should be considered in the developing European region (Table 4)

\section{Southeast Asia and western pacific}

In the Southeast Asia region, epidemics occur in the equatorial region first (Indonesia), then appear in the countries above the equator during the following months. (Thailand, Vietnam, Malaysia), similar to the observation in an earlier study. ${ }^{13}$

In the Indian subcontinent, RSV seasons started from Pune in west India ${ }^{61}$ and Dhaka in Bangladesh, ${ }^{62}$ followed by Bhaktapur in Nepal, ${ }^{63,64}$ New Delhi ${ }^{65,66}$ and Ballabgarh in north India. ${ }^{67}$ The epidemics followed a south to north progression as previously described, except one study from Kolkata, India ${ }^{68}$ where the RSV season was typically earlier during the rainy season. ${ }^{13,14}$ Nevertheless, this study has shown contradictory results. There is a potential for substantial regional and geographic differences of RSV seasonality in China but only 3 studies were published in English and retrieved from the literature search. ${ }^{69-72}$ Huge population, results discrepancy and evidence of climate change in China warrant further studies (Table 5).

\begin{tabular}{|c|c|c|c|c|c|c|c|}
\hline \multirow[t]{2}{*}{ Country / Location } & \multirow[t]{2}{*}{ Study Period } & \multirow[t]{2}{*}{ Peaked Season } & \multicolumn{5}{|c|}{ Peaked Months } \\
\hline & & & JAN FEB & MAR APR & MAY JUN JUL & AUG SEP & OCT NOV DEC \\
\hline Mozambique, Manhica ${ }^{15}$ & Feb 99 - Jan 00 & Rainy & & & & & \\
\hline Mozambique, Manhica ${ }^{16}$ & Oct 98 - May 00 & Rainy & & & & & \\
\hline Mozambique, Manhica ${ }^{17}$ & Sep $06-\operatorname{Sep} 07$ & Winter & & & & & \\
\hline Kenya, Kilifi ${ }^{18}$ & Jan 02 -Jan 03 & Rainy & & & & & \\
\hline Kenya, Kilifi ${ }^{19}$ & Jan 02 -Dec 07 & Rainy & & & & & \\
\hline Kenya, Kilifi ${ }^{20}$ & Jan $07-$ Dec 07 & Rainy & & & & & \\
\hline South Africa, Durban ${ }^{21 *}$ & Jun 99 - May 00 & Rainy & & & & & \\
\hline South Africa, Johannes berg ${ }^{22}$ & Mar 98 - Dec 04 & Autumn - winter & & & & & \\
\hline South Africa, Johannesburg ${ }^{15 *}$ & Apr 00 -Mar 01 & Winter & & & & & \\
\hline Nigeria, Ibadan ${ }^{15 *}$ & Jun 99 - May 0I & Dry & & & & & \\
\hline Nigeria, Ibadan ${ }^{23}$ & $\mathrm{n} / \mathrm{a}$ & Rainy & & & & & \\
\hline Ghana, Kumasi ${ }^{24}$ & Jan $08-$ Dec 08 & Rainy & & & & & \\
\hline Senegal, Sine Saloum ${ }^{25}$ & Jul 07 -Dec 07 & Rainy & & & & & \\
\hline Gambia, Banjul 26* & Oct 93 - Oct 02 & Rainy & & & & & \\
\hline Gambia, Fajara, Sibanor 27 & Oct $93-$ Dec 97 & Rainy & & & & & \\
\hline
\end{tabular}

RSV peaked months shaded $*=$ detected throughout year. 
Table 2 Seasonality of RSV respiratory illnesses in Latin America

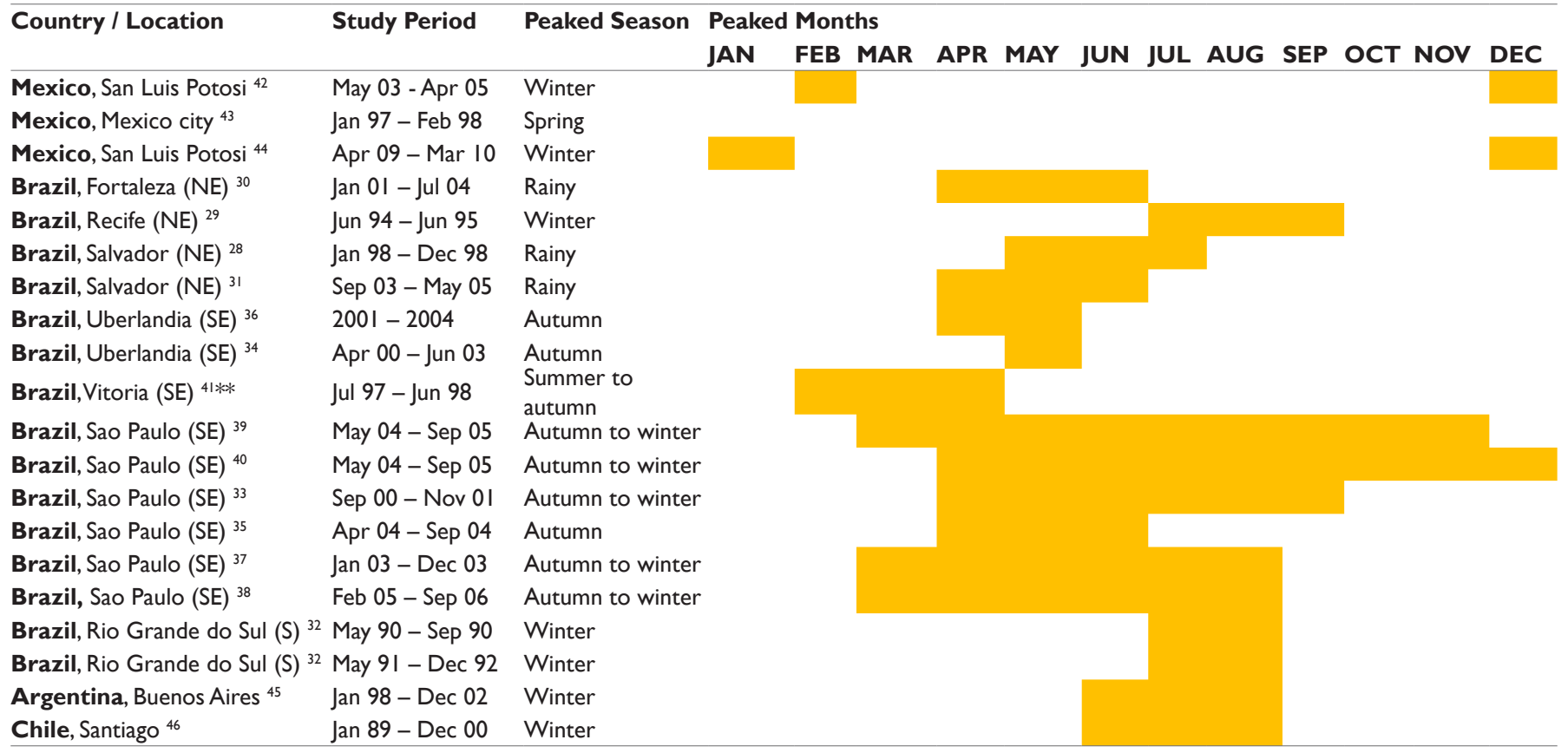

RSV peaked months shaded $* *=$ detected throughout year except August and December, N/A = not available.

$\mathrm{NE}=$ Northeast Brazil, SE=Southeast Brazil, $\mathrm{S}=$ Southern Brazil.

Table 3 Seasonality of RSV respiratory illnesses in Eastern Mediterranean

\begin{tabular}{|c|c|c|c|c|c|c|c|c|c|c|c|c|}
\hline \multirow[t]{2}{*}{ Country / Location } & \multirow[t]{2}{*}{ Study Period } & \multicolumn{11}{|c|}{ Peaked Season Peaked Months } \\
\hline & & & JAN & FEB & MAR & APR & MAY & JUN & JUL & AUG & SEP & OCT NOV DEC \\
\hline Iran, Tehran ${ }^{47}$ & Nov 97 - Mar 98 & Winter & & & & & & & & & & \\
\hline Iran, Rasht ${ }^{48}$ & Nov 03 - Mar 04 & Winter & & & & & & & & & & \\
\hline Iran, Tehran ${ }^{49}$ & Mar 08 - May 09 & Winter & & & & & & & & & & \\
\hline Jordan, Amman ${ }^{50}$ & Sep 02 - Mar 04 & Winter & & & & & & & & & & \\
\hline Jordan, Amman ${ }^{51}$ & Dec 03 - May 04 & Winter & & & & & & & & & & \\
\hline Jordan, Amman ${ }^{52}$ & Jan 07 - Mar 07 & Winter & & & & & & & & & & \\
\hline Kuwait, Kuwait city ${ }^{53}$ & $\mathrm{n} / \mathrm{a}$ & Winter & & & & & & & & & & \\
\hline UA Emirates, Abu Dhabi ${ }^{54}$ & Sep 0I - Nov 0I & Winter & & & & & & & & & & \\
\hline Egypt, Cairo ${ }^{55}$ & Dec 06 - Nov 07 & Winter & & & & & & & & & & \\
\hline Pakistan, Islamabad ${ }^{56}$ & Oct $99-$ Apr 00 & Winter & & & & & & & & & & \\
\hline Yemen, Sana'a ${ }^{57}$ & Oct 02 - May 03 & Winter & & & & & & & & & & \\
\hline
\end{tabular}

RSV peaked months shaded.

Table 4 Seasonality of RSV respiratory illnesses in Europe

\section{Country/Location $\quad$ Study Period Peaked Season Peaked Months}

Serbia, Belgrade ${ }^{59} \quad$ Nov 08 - Mar 09 Winter

Turkey, Istanbul $60 \quad$ Oct 06 - Mar 07 Winter

Russia, St. Petersburg \&Tomsk ${ }^{58}$ Sep 08 -Apr 09 Spring

JAN FEB MAR APR MAY JUN JUL AUG SEP OCT NOV DEC

Table 5 Seasonality of RSV respiratory illnesses in Asia and Western Pacific

\begin{tabular}{|c|c|c|c|c|c|c|c|c|c|c|c|}
\hline \multirow[t]{2}{*}{ Country/Location } & \multirow[t]{2}{*}{ Study Period } & \multirow[t]{2}{*}{ Peaked Season } & \multicolumn{3}{|c|}{ Peaked Months } & \multirow[b]{2}{*}{ APR } & \multirow[b]{2}{*}{ JUN JUL } & \multirow[b]{2}{*}{ AUG SEP } & \multirow[b]{2}{*}{ OCT } & \multirow{2}{*}{\multicolumn{2}{|c|}{ NOV DEC }} \\
\hline & & & JAN & FEB & MAR & & & & & & \\
\hline Indonesia, Cikutra \& Ujung berung ${ }^{68}$ & ${ }^{8}$ Feb 99- Jan 0I & Rainy & & & & & & & & & \\
\hline Indonesia, Lombok island ${ }^{69}$ & Jan 00-Dec 02 & Rainy & & & & & & & & & \\
\hline Indonesia, Cikutra \& Ujung berung 70 & ${ }^{0}$ Feb 99-May 0I & Rainy & & & & & & & & & \\
\hline Indonesia, Lombok island $71 * * *$ & Jan 00-Dec 0I & Rainy & & & & & & & & & \\
\hline Indonesia, Lombok island 72 & Jan 99-Dec 0I & Rainy & & & & & & & & & \\
\hline Malaysia, Kuala Lumpur ${ }^{73 *}$ & 1982- 2008 & Rainy & & & & & & & & & \\
\hline Malaysia, Kuala Lumpur ${ }^{74}$ & Jan 82- Dec 97 & Rainy & & & & & & & & & \\
\hline
\end{tabular}


Table Continued...

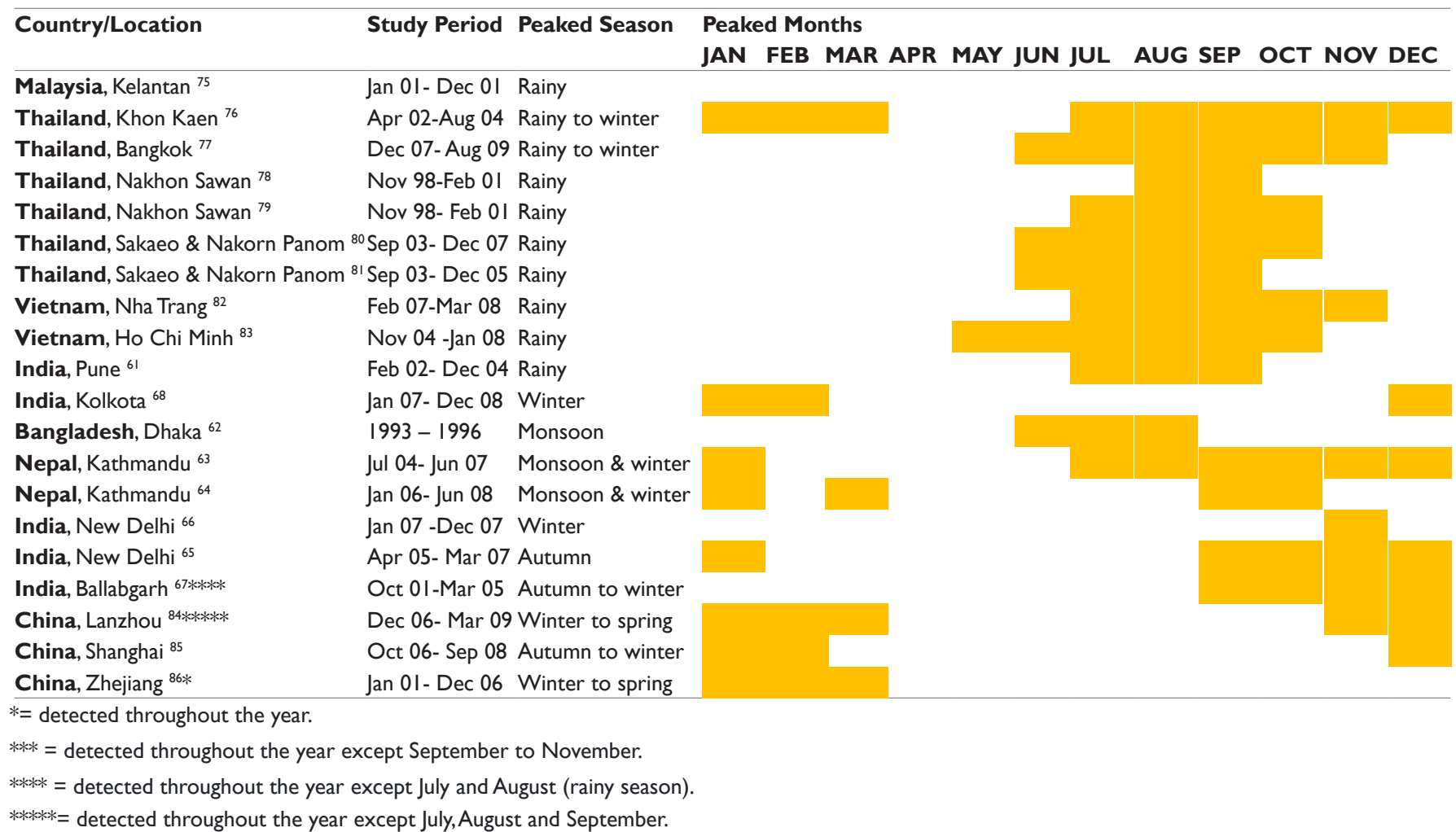

\section{Limitations of the current literature review}

Despite various literature databases utilized to make this review as exhaustive as possible, some limitations exist. ${ }^{73}$ Only English literature was searched. This likely biased the findings by excluding some studies from certain regions such as China, and some countries in Latin America, Russia, and the Middle East where there may be substantial information in local language publications. ${ }^{74-76}$

\section{Conclusion}

The season in which RSV epidemics occur typically depends on geographical location and altitude. It is likely that several factors interact in complex ways in the development of epidemics under favorable climatic conditions ${ }^{77}$. Despite the increasing number of epidemiological studies of RSV-LRTI published over the past decade in developing countries, there are still clearly many areas that merit further study. ${ }^{78-80}$ There is still a need to establish further RSV surveillance studies to improve the incidence estimates and to explore the extent to which national and regional variation in RSV infection rates exist in countries where there is a high burden and high mortality attributable to LRTI but lack of understanding of local RSV epidemiology. Future epidemiological studies should be conducted over adequate time periods to offset bias from temporal variation and to assess the long term variability of RSV seasonality. ${ }^{81-85}$ Baseline data on incidence and seasonality of each geographic region can be useful in planning RSV vaccine trials in various geographies. ${ }^{86}$

\section{Author contribution}

SS, EP and MS contributed to the design and interpretation of data for this manuscript. SS, MS and DD were responsible for drafting the work and revising it critically for intellectual content. All authors agree to be fully accountable for ensuring the integrity and accuracy of the work and read and approved the final manuscript.

\section{Acknowledgments}

None.

\section{Conflicts of interest}

None.

\section{Funding}

None.

\section{References}

1. Global Burden of Disease (GBD) Compare. In: Compare G (Ed.), Institute for Health Metrics and Evaluation (IHME): The Lancet, USA. 2010

2. Liu L, Johnson HL, Cousens S, et al. Global, regional, and national causes of child mortality: an updated systematic analysis for 2010 with time trends since 2000. The Lancet. 2012;379(9832): 2151-2161.

3. Lozano R, Naghavi M, Foreman K, et al. Global and regional mortality from 235 causes of death for 20 age groups in 1990 and 2010: a systematic analysis for the Global Burden of Disease Study 2010. The Lancet. 2012;380(9859):2095-2128.

4. Simoes EAF, Cherian T, Chow J, et al. Acute Respiratory Infections in Children. In: Jamison et al. (Eds.), Disease Control Priorities in Developing Countries. ( 2nd edn), Washington (DC): World Bank, USA. 2006.

5. Tregoning JS, Schwarze J. Respiratory viral infections in infants: causes, clinical symptoms, virology, and immunology. Clin Microbiol Rev. 2010;23(1):74-98.

6. Hall CB, Weinberg GA, Iwane MK, et al. The burden of respiratory syncytial virus infection in young children. $N$ Engl $J$ Med. 2009;360(6):588-598

7. Pickering LK. Respiratory syncytial virus. In: Carol et al. (Eds.), Red Book: 2009 Report of the Committee on Infectious Diseases. (28th edn), American Academy of Pediatrics, USA. 2009. p. 560. 
8. Center for Disease Control and Prevention. Respiratory syncytial virus (RSV). 2015.

9. Panozzo CA, Fowlkes AL, Anderson LJ. Variation in timing of respiratory syncytial virus outbreaks: lessons from national surveillance. Pediatr Infect Dis J. 2007;26(11 suppl):S41-S45.

10. Amber KH, Mila MP, Marika KI, et al. Respiratory syncytial virus United States, July 2012-June 2014. MMWR Morb Mortal Wkly Rep. 2014;63(48):1133-1136

11. Centers for Disease Control and Prevention (CDC). Respiratory syncytial virus-United States, July 2011-January 2013. MMWR Morb Mortal Wkly Rep. 2013;62(8):141-144.

12. Light MJ. Variability of respiratory syncytial: virus seasonality and mortality. In: Mostafa Ghanei (Ed.), Ross University Medical School, Commonwealth of Dominica, Caribbean, USA. 2012.

13. Stensballe LG, Devasundaram JK, Simoes EA. Respiratory syncytia virus epidemics: the ups and downs of a seasonal virus. Pediatr Infect Dis J. 2003;22(2 Suppl):S21-S32.

14. Weber MW, Mulholland EK, Greenwood BM. Respiratory syncytial virus infection in tropical and developing countries. Tropical Medicine \& International Health. 1998;3(4):268-280.

15. Robertson SE, Roca A, Alonso P, et al. Respiratory syncytial virus infection: denominator-based studies in Indonesia, Mozambique, Nigeria and South Africa. Bulletin of the World Health Organization. 2004;82(12):914-922.

16. Loscertales MP, Roca A, Ventura PJ, et al. Epidemiology and clinical presentation of respiratory syncytial virus infection in rural area of southern Mozambique. Pediatr Infect Dis J. 2002;21(2):148-155.

17. O'Callaghan-Gordo C, Bassat Q, Morais L, et al. Etiology and epidemiology of viral pneumonia among hospitalized children in rural Mozambique: a malaria endemic area with high prevalence of HIV. Pediatr Infect Dis J. 2011;30(1):39-44.

18. Nokes DJ, Okiro EA, Ngama M, et al. Respiratory syncytial virus epidemiology in a birth cohort from Kilifi district, Kenya: infection during the first year of life. The Pediatric Infectious Disease Journal. 2004;190(10):1828-1832.

19. Nokes DJ, Ngama M, Bett A, et al. Incidence and severity of respiratory syncytial virus pneumonia in rural Kenyan children identified through hospital surveillance. Clin Infect Dis. 2009;49(9):1341-1349.

20. Berkley JA, Munywoki P, Ngama M, et al. Viral etiology of severe pneumonia among Kenyan infants and children. JAMA. 2010;303(20):2051-2057.

21. Jeena PM, Ayannusi OE, Annamalai K, et al. Risk factors for admission and the role of respiratory syncytial virus specific cytotoxic Tlymphocyte responses in children with acute bronchiolitis. S Afr Med J. 2003;93:291-294.

22. Madhi SA, Kuwanda L, Cutland C, et al. Five year cohort study of hospitalization for respiratory syncytial virus associated lower respiratory tract infection in African children. J Clin Virol. 2006; 36(3):215-221.

23. Johnson AW, Osinusi K, Aderele WI, et al. Etiologic agents and outcome determinants of community-acquired pneumonia in urban children: A hospital based study. J Nat Med Assoc. 2008;100(4):370-385.

24. Kwofie TB, Anane YA, Nkrumah B, et al. Respiratory viruses in children hospitalized for acute lower respiratory tract infection in Ghana. Virol J. 2012;9:78.

25. Niang MN, Diop OM, Sarr FD, et al. Viral etiology of respiratory infections in children under 5 years old living in tropical rural areas of Senegal: the EVIRA project. J Med Virol. 2010;82(5):866-872.
26. van der Sande MA, Goetghebuer T, Sanneh M, et al. Seasonal variation in RSV epidemics in the Gambia, West Africa. Pediatr Infect Dis J. 2004;23:73-74.

27. Weber MW, Milligan P, Sanneh M, et al. An epidemiological study of RSV infection in the Gambia. Bulletin of the World Health Organization. 2002;80(7):562-568.

28. Moura FE, Borges LC, Portes SA, et al. Respiratory syncytial virus infections during an epidemic period in Salvador, Brazil. Viral antigenic group analysis and description of clinical and epidemiological aspects. Memorias do Instituto Oswaldo Cruz. 2003;98(6):739-743.

29. Nacul LC, Kirkwood BR, Carneiro AC, et al. Aetiology and clinical presentation of pneumonia in hospitalized and outpatient children in northeast Brazil and risk factors for severity. J Health Popul Nutr. 2005;23(1):6-15.

30. Moura FE, Nunes IF, Silva GB, et al. Respiratory syncytial virus infections in northeastern Brazil seasonal trends and general aspects. The American Journal of Tropical Medicine and Hygiene. 2006;74(1):165-167.

31. Nascimento-Carvalho CM, Cardoso MR, Barral A, et al. Seasonal patterns of viral and bacterial infections among children hospitalized with community-acquired pneumonia in a tropical region. Scandinavian Journal of Infectious Diseases. 2010;42(11-12):839-844.

32. Straliotto SM, Siqueira MM, Muller RL, et al. Viral etiology of acute respiratory infections among children in Porto Alegre, RS, Brazil. Revista da Sociedade Brasiliera de Medicina Tropical. 2002; 35(4):283-291.

33. Patrícia ARB, João MGC, dos Santos PK, et al. Human Respiratory syncytial virus detection in children admitted at a community hospital in Botucatu, SP, Brazil. Brazilian Journal of Microbiology. 2004;35:348-351.

34. Calegari T, Queiroz DA, Yokosawa J, et al. Clinical epidemiological evaluation of respiratory syncytial virus infection in children attended in a public hospital in midwestern Brazil. Braz J Infect Dis. 2005;9(2):156-161.

35. Riccetto AG, Ribeiro JD, Silva MT, et al. Respiratory syncytial virus in infants hospitalized for acute lower respiratory tract disease: incidence and associated risks. Braz J Infect Dis. 2006; 10(5):357-361.

36. Ali SA, Williams JV, Chen Q, et al. Respiratory viruses in children $<5$ years old with acute respiratory disease from 2001-2004 in Uberlandia MG, Brazil. Memorias do Instituto Oswaldo Cruz. 2006;101:301-306.

37. Thomazelli LM, Vieira S, Leal AL, et al. Surveillance of eight respiratory viruses in clinical samples of pediatric patients in southeast Brazil. $J$ Pediatr. 2007;83(5):422-428.

38. Pecchini R, Berezin EN, Felício MC, et al. Incidence and clinical characteristics of the infection by the respiratory syncytial virus in children admitted in Santa Casa de Sao Paulo hospital. Braz J Infect Dis. 2008;12(6):476-479.

39. Salomão Junior JB, Gardinassi LG, Simas PV, et al. Human respiratory syncytial virus in children hospitalized for acute lower respiratory infection. $J$ de Pediatr (Rio J). 2011;87(3):219-224.

40. Gardinassi LG, Marques Simas PV, Salomão JB, et al. Seasonality of viral respiratory infections in Southeast Brazil: the influence of temperature and air humidity. Braz J Microbiol. 2012;43(1): 98-108.

41. Checon RE, Siqueira MM, Lugon AK, et al. Short report: Seasonal pattern of Respiratory syncytial virus in a region with a tropical climate in southeastern Brazil. Am J Trop Med Hyg. 2002;67: 490-491.

42. Noyola DE, Zuviri-González A, Castro-García JA, et al. Impact of respiratory syncytial virus on hospital admissions in children younger than 3 years of age. $J$ Infect. 2007;54(2):180-184. 
43. Cabello C, Manjarrez ME, Olvera R, et al. Frequency of viruse associated with acute respiratory infection in children younger than five years of age at a locality of Mexico city. Mem de Inst Oswaldo Cruz. 2006;101(1):21-24.

44. Locate-Salas F, Matienzo-Serment L, Monjarás-Ávila C, et al. Pandemic influenza A (H1N1) 2009 and respiratory syncytial virus associated hospitalizations. J Infect. 2010;61(5):382-390.

45. Viegas M, Barrero PR, Maffey AF, et al.Respiratory viruses seasonality in children under five years of age in Buenos Aires, Argentina: a five year analysis. J Infect. 2004;49(3):222-228.

46. Avendaño LF, Palomino MA, Larrañaga C. Surveillance for Respiratory syncytial virus in infants hospitalized for acute lower respiratory infection in Chile (1989 to 2000). J Clin Microbiol . 2003;41(10):4879-4882.

47. Milani M. Respiratory syncytial virus infection among young children with acute respiratory infection. Acta Medica Iranica. 2003;41(4):269-272.

48. Naghipour M, Cuevas LE, Bakhshinejad T, et al. Contribution of viruses, Chlamydia spp. And Mycoplasma pneumoniae to acute respiratory infection in Iranian children. $J$ Trop Pediatr. 2007; 53(3):179-184.

49. Malekshahi SS, Azad TM, Yavarian J, et al. Molecular detection of respiratory viruses in clinical specimens from children with acute respiratory disease in Iran. Pediatr Infect Disease J. 2010; 29(10):931-933.

50. Al-Toum R, Bdour S, Ayyash H. Epidemiology and clinical characteristics of respiratory syncytial virus infections in Jordan. $J$ Trop Pediatr. 2006;52(4):282-287.

51. Tran DN, Pham TM, Ha MT, et al. Molecular epidemiology and disease severity of respiratory syncytia virus in relation to other potential pathogens in children hospitalized with acute respiratory infection in Jordan. Journal of Medical Virology. 2008;8(1):168-174.

52. Khuri-Bulos N, Williams JV, Shehabi AA, et al. Burden of respiratory syncytial virus in hospitalized infants and young children in Amman, Jordan. Scandinavian J Infect Dis. 2010; 42(5):368-374.

53. Khadadah M, Essa S, Higazi Z, et al. Respiratory syncytial virus and human rhinoviruses are the major causes of severe lower respiratory tract infections in Kuwait. J Med Virol. 2010;82(8):1462-1467.

54. Howidi M, Rajah J, Abushrar Z, et al. The severity of respiratory syncytial virus bronchiolitis in young infants in the United Arab Emirates. Journal of Tropical Pediatrics. 2007;53(1):22-26.

55. Fattouh AM, Mansi YA, El-Anany MG, et al. Acute lover respiratory tract infection due to respiratory syncytial virus in a group of Egyptian children under 5 years of age. Ital J Pediatr. 2011;37:14.

56. Tariq WU, Waqar T, Ali S, et al. Winter peak of respiratory syncytial virus in Islamabad. Tropical Doctor. 2005;35(1):28-29.

57. Al-Sonboli N, Hart CA, Al-Aeryani A, et al. Respiratory syncytial virus and human metapneumovirus in children with acute respiratory infections in Yemen. Pediatr Infect Dis J. 2005;24(8):734-736.

58. Tatochenko V, Uchaikin V, Gorelov A, et al. Epidemiology of respiratory syncytial virus in children $\leq 2$ years of age hospitalized with LRTI in the Russian Federation: a prospective multicenter study. Clin Epidemiol. 2010;2:221-227.

59. Savić N, Janković B, Minić P, et al. Clinical characteristics of respiratory syncytial virus infection in neonates and young infants. Vojnosanitetsky Pregled. 2011;68(3):220-224.

60. Hatipoğlu N, Somer A, Badur S, et al. Viral etiology in hospitalized children with acute lower respiratory tract infection. Turk J Pediatr. 2011;53:508-516.

61. Yeolekar LR, Damle RG, Kamat AN, et al. Respiratory viruses in acute respiratory tract infections in western India. Indian $J$ Pediatr 2008;75(4):341-345.
62. Hasan K, Jolly P, Marquis G, et al. Viral etiology of pneumonia in a cohort of newborns till 24 months of age in rural Mirzapur, Bangladesh. Scand J Infect Dis. 2006;38(8):690-695.

63. Mathisen M, Strand TA, Sharma BN, et al. RNA viruses in community acquired childhood pneumonia in semi urban Nepal: a cross sectional study. BMC medicine. 2009;7:35.

64. Mathisen M, Basnet S, Sharma A, et al. RNA viruses in young Nepalese children hospitalized with severe pneumonia. Pediatr Infect Dis J. 30(12):1032-1036.

65. Bharaj P, Sullender WM, Kabra SK, et al. Respiratory viral infections detected by multiplex PCR among pediatric patients with lower respiratory tract infections seen at an urban hospital in Delhi from 2005 to 2007. Virol J. 2009;6:89.

66. Kaur C, Chohan S, Khare S, et al. Respiratory viruses in acute bronchiolitis in Delhi. Indian Pediatr. 2010;47(4):342-343.

67. Broor S, Parveen S, Bharaj P, et al. A prospective three-year cohort study of the epidemiology and virology of acute respiratory infection of children in rural India. PloS One. 2007;2(6):e491.

68. Agrawal AS, Sarkar M, Chakrabarti S, et al. Comparative evaluation of real-time PCR and conventional RT-PCR during a 2 year surveillance for influenza and respiratory syncytial virus among children with acute respiratory infections in Kolkota, India reveals a distinct seasonality of infection. Journal of Medical Microbiology. 2009;58(Pt 12):1616-1622.

69. Omer SB, Sutanto A, Sarwo H, et al. Climatic, temporal, and geographic characteristics of respiratory syncytial virus disease in a tropical island population. Epidemiology and Infection . 2008;136(10):1319-1327.

70. Simões EA, Mutyara K, Soh S, et al. The epidemiology of respiratory syncytial virus lower respiratory tract infection in children less than 5 years of age in Indonesia. Pediatr Infect Dis J. 2011;30:778-784.

71. Djelantik IG, Gessner BD, Soewignjo S, et al. Incidence and clinical features of hospitalization because of respiratory syncytial virus lower respiratory tract illness among children less than two years of age in a rural Asian setting. Pediatr Infect Dis J. 2003;22(2):150-157.

72. Djelantik IG, Gessner BD, Sutanto A, et al. Case fatality proportions and predictive factors for mortality among children hospitalized with severe pneumonia in a rural developing country setting. J Trop Pediatr. 2003;49(6):327-332.

73. Khor CS, Sam IC, Hooi PS, et al. Epidemiology and seasonaltiy of respiratory viral infection in hospitalized children in Kuala Lumpur, Malaysia: a retrospective study of 27 years. BMC Pediatrics. 2012;12:32.

74. Chan PW, Chew FT, Tan TN, et al. Seasonal variation in respiratory syncytial virus chest infection in the tropics. Pediatric Pulmonology. 2002;34(1):47-51

75. Leung AK, Kellner JD, Davies HD. Respiratory syncytial virus and bronchiolitis. J Natl Med Assoc. 2005;97(12):1708-1713.

76. Teeratakulpisarn J, Ekalaksananan T, Pientong C, et al. Human metapneumovirus and respiratory syncytial virus detection in young children with acute bronchiolitis. Asian Pacific J Allergy Immunol. 2007;25(2-3):139-145.

77. Suntarattiwong P, Sojisirikul K, Sitaposa P, et al. Clinical and epidemiological characteristics of respiratory syncytial virus and influenza virus associated hospitalization in urban Thai infants. $J$ Med Assoc Thai. 2011;94:s164-s171.

78. Siritantikorn S, Puthavathana P, Suwanjutha S, et al. Acute viral lower respiratory infection in children in a rural community in Thailand. $J \mathrm{Med}$ Assoc Thai. 2002;85(Suppl 4):s1167-s1675.

79. Suwanjutha S, Sunakorn P, Chantarojanasiri T, et al. Respiratory syncytial virus-associated lower respiratory tract infection in under-5 year-old children in a rural community of central Thailand population based study. Journal of the Medical Association of Thailand. 2002;85:s1111-s1119. 
80. Fry AM, Chittaganpitch M, Baggett HC, et al. The burden of hospitalized lower respiratory tract infection due to respiratory syncytial virus in rural Thailand. PLoS One. 2010;5(11):1-7.

81. Olsen SJ, Thamthitiwat $\mathrm{S}$, Chantra $\mathrm{S}$, et al. Incidence of respiratory pathogens in persons hospitalized with pneumonia in two provinces in Thailand. Epidemiology and Infection. 2010; 138:1811-1822.

82. Yoshida LM, Suzuki M, Yamamoto T, et al. Viral pathogens associated with acute respiratory infection in central Vietnamese children. The Pediatric Infectious Disease Journal. 2010;29(1):75-77.

83. Do AH, van Doorn HR, Nghiem MN, et al. Viral etiologies of acute respiratory infections among hospitalized Vietnamese children in the Ho Chi Minh city 2004-2008. PLos One. 2011;6(3):1-9.
84. Zhang RF, Jin Y, Xie ZP, et al. Human respiratory syncytial virus in children with acute respiratory tract infection in China. J Clin Microbiol. 2000;48(11):4193-4199

85. Wang W, Cavailler P, Ren P, et al. Molecular monitoring of causative viruses in child acute respiratory infection in endemo-epidemic situations in Shanghai. J Clin Virol. 2010;49(3):211-218.

86. Tang LF, Wang TL, Tang HF, et al. Viral pathogens of acute lower respiratory tract infection in China. Indian Pediatrics. 2008;45(12):971-975. 